Marquette University

e-Publications@Marquette

Biological Sciences Faculty Research and

Publications

Biological Sciences, Department of

$9-2001$

\title{
Functional and Structural Adaptations of Skeletal Muscle to Microgravity
}

Robert Fitts

Marquette University, robert.fitts@marquette.edu

Danny R. Riley

Medical College of Wisconsin

Jeffrey J. Widrick

Oregon State University

Follow this and additional works at: https://epublications.marquette.edu/bio_fac

Part of the Biology Commons

\section{Recommended Citation}

Fitts, Robert; Riley, Danny R.; and Widrick, Jeffrey J., "Functional and Structural Adaptations of Skeletal Muscle to Microgravity" (2001). Biological Sciences Faculty Research and Publications. 9.

https://epublications.marquette.edu/bio_fac/9 


\title{
Functional and structural adaptations of skeletal muscle to microgravity
}

\author{
Robert H. Fitts ${ }^{1 *}$ \\ Department of Biology, Marquette University \\ Milwaukee, WI \\ Danny R. Riley ${ }^{2}$ \\ Department of Cellular Biology and Anatomy, Medical College of \\ Wisconsin \\ Milwaukee, WI \\ Jeffrey J. Widrick ${ }^{3}$ \\ Department of Exercise and Sport Sciences, Oregon State \\ University \\ Corvallis, OR
}

\section{Summary}

Our purpose is to summarize the major effects of space travel on skeletal muscle with particular emphasis on factors that alter function. The primary deleterious changes are muscle atrophy and the associated decline in peak force and power. Studies on both rats and humans demonstrate a rapid loss of cell mass with microgravity. In rats, a reduction in muscle mass of up to $37 \%$ was observed within 1 week. For both species, the antigravity soleus muscle showed greater atrophy than the fast-twitch gastrocnemius. However, in the rat, the slow type I fibers atrophied more than the fast type II fibers, while in humans, the fast type II fibers were at least as susceptible to space- 
induced atrophy as the slow fiber type. Space flight also resulted in a significant decline in peak force. For example, the maximal voluntary contraction of the human plantar flexor muscles declined by $20-48 \%$ following 6 months in space, while a $21 \%$ decline in the peak force of the soleus type I fibers was observed after a 17-day shuttle flight. The reduced force can be attributed both to muscle atrophy and to a selective loss of contractile protein. The former was the primary cause because, when force was expressed per cross-sectional area $\left(\mathrm{kNm}^{-2}\right)$, the human fast type II and slow type I fibers of the soleus showed no change and a $4 \%$ decrease in force, respectively. Microgravity has been shown to increase the shortening velocity of the plantar flexors. This increase can be attributed both to an elevated maximal shortening velocity $\left(V_{0}\right)$ of the individual slow and fast fibers and to an increased expression of fibers containing fast myosin. Although the cause of the former is unknown, it might result from the selective loss of the thin filament actin and an associated decline in the internal drag during cross-bridge cycling. Despite the increase in fiber $V_{0}$, peak power of the slow type I fiber was reduced following space flight. The decreased power was a direct result of the reduced force caused by the fiber atrophy. In addition to fiber atrophy and the loss of force and power, weightlessness reduces the ability of the slow soleus to oxidize fats and increases the utilization of muscle glycogen, at least in rats. This substrate change leads to an increased rate of fatigue. Finally, with return to the $1 \mathrm{~g}$ environment of earth, rat studies have shown an increased occurrence of eccentric contraction-induced fiber damage. The damage occurs with reloading and not in-flight, but the etiology has not been established.

\section{KEY WORDS}

- microgravity

- skeletal muscle

- muscle

- atrophy

- contractile properties.

\section{Introduction}

A major goal of the international space community is a manned mission to Mars. Before this can become a reality, significant biological, psychological and environmental problems must be solved (Nicogossian et al., 1994). One of the major biological problems concerns the wasting of bone and skeletal muscle. The susceptibility of these tissues to space flight has been known since the Skylab missions

[Journal of Experimental Biology, Vol. 204, No. 18 (September 2001): pg. 3201-3208. Publisher Link. This article is (C) Company of Biologists and permission has been granted for this version to appear in e-Publications@Marquette. Company of Biologists does not grant permission for this article to be further copied/distributed or hosted elsewhere without the express permission from Company of Biologists. 
of the mid-1970s. The purpose of this paper is to highlight some of the main effects of microgravity on skeletal muscle that we reviewed in detail previously (Fitts et al., 2000) and to present new data on the effects of space flight on muscle glycogen. We will focus on the functional properties of muscle (force, shortening velocity and power) and discuss the possible cellular mechanisms for the observed changes in function induced by space flight.

\section{Muscle diameter and force}

Research from the Cosmos biosatellite and US Shuttle programs has demonstrated that muscle atrophy in space-flown rats occurred rapidly, with up to $37 \%$ reductions in muscle mass within 1 week (Fitts et al., 2000). In rats, antigravity slow muscles atrophy more than fasttwitch muscles, and extensors more than flexors (Jiang et al., 1992; Ohira et al., 1992; Tischler et al., 1993). Human data from Skylab and Mir suggest that leg extensors atrophy and lose peak force faster than flexors, but when the flight duration is long enough (>200 days) both groups of muscles show similar declines of approximately $30 \%$ in isokinetic strength (Greenleaf et al., 1989).

Until recently, the effects of space flight on muscle force or strength were confined to studies of whole-muscle function. While providing important information regarding the extent of atrophy and loss of strength, such studies could not distinguish selective effects on slow versus fast fibers or the cellular mechanism for the loss of function. A cellular analysis of the calf muscles demonstrates a clear difference in the response of rats and humans to microgravity. For both species, fibers from the antigravity slow soleus showed greater atrophy than fibers from the fast-twitch gastrocnemius. However, when fibers within a given muscle were examined, rats, but not humans, showed selective atrophy of the antigravity slow type I fiber (see Fig.1)(Fitts et al., 2000). Data on the vastus lateralis and soleus muscles suggest that in humans the fast type II fibers may be even more susceptible to microgravity-induced atrophy than the slow type I fiber (Fitts et al., 2000). Following an 11-day human space flight, Edgerton et al. (Edgerton et al., 1995) observed a significant decline in the cross-sectional area of fibers from the vastus lateralis, with the decline being greatest in the IIb fibers and least in the type I fibers.

[Journal of Experimental Biology, Vol. 204, No. 18 (September 2001): pg. 3201-3208. Publisher Link. This article is (C) Company of Biologists and permission has been granted for this version to appear in e-Publications@Marquette. Company of Biologists does not grant permission for this article to be further copied/distributed or hosted elsewhere without the express permission from Company of Biologists. 
Widrick et al. (Widrick et al., 1999) made similar observations for the soleus: following a 17-day flight, the type IIa fiber cross-sectional area declined by $26 \%$ compared with a $15 \%$ reduction in the cross-sectional area of the slow type I fiber. Fig. 1 shows an electron micrograph of soleus muscle fibers obtained pre- and post-flight from astronaut B (Widrick et al., 1999). The space-flight-induced atrophy of the myofibrils is clearly observed.

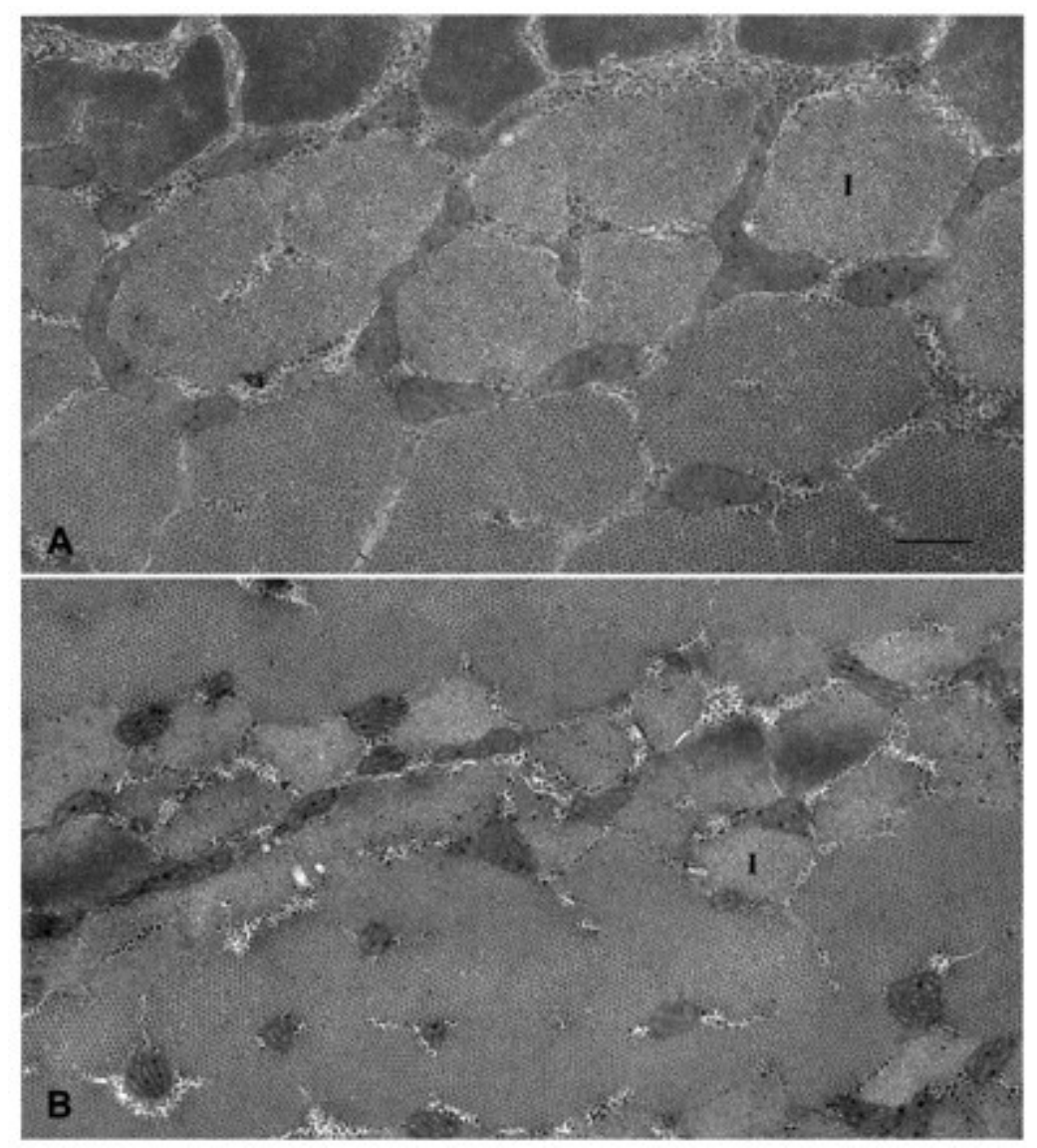

Fig. 1.

Cross section electron micrographs of soleus muscle fibers obtained pre-flight $(A)$ and post-flight (B) from astronaut B of the 17-day STS-78 shuttle flight. The micrographs show the spaceflight-induced atrophy of the myofibrils and the rounding of the mitochondria. The I-bands of representative myofibrils are labeled (I). The amount of glycogen-like particles (the black dots surrounding the fibrils) is similar in both fibers. Scale bar, $0.5 \mu \mathrm{m}$.

Data from both Skylab and Mir have demonstrated that space flight reduces the peak force of limb skeletal muscle (Fitts et al.,

[Journal of Experimental Biology, Vol. 204, No. 18 (September 2001): pg. 3201-3208. Publisher Link. This article is (C) Company of Biologists and permission has been granted for this version to appear in e-Publications@Marquette. Company of Biologists does not grant permission for this article to be further copied/distributed or hosted elsewhere without the express permission from Company of Biologists. 
2000). The decline in peak force can be attributed both to muscle atrophy and to a selective loss of contractile protein. Baldwin et al. (Baldwin et al., 1990) showed a significant decline in myofibril yield (mgproteing ${ }^{-1}$ muscle) in the rat slow-twitch vastus intermedius but not in the fast-twitch vastus lateralis following a 12.5-day space flight. The authors concluded that the decline in myofibrillar protein content was attributable to a reduced slow (type I) and intermediate (presumably type IIa) myosin content. In humans, there are no published data on muscle protein content following space flight; however, the loss of force per cross-sectional area in the slow type I fibers suggests that slow myosin was also selectively lost in humans (Widrick et al., 1999).

Recently, we studied the contractile properties of individual fibers isolated from the soleus and gastrocnemius of four astronauts before and immediately after a 17-day space flight (STS-78). Consistent with previously published whole-muscle studies (Skylab and Mir) and single-fiber analyses of the human vastus lateralis, considerable variability was noted in the degree of cell atrophy and the loss of peak force among astronauts (Widrick et al., 1999). Studies of Mir cosmonauts after 6 months of space flight showed declines of calf plantar flexor volume ranging from 6 to $20 \%$, while maximal voluntary contractions (MVCs) of the same muscle group declined by $20-48 \%$ (Zange et al., 1997). Recently, a similar result was reported by Lambertz et al. (Lambertz et al., 2000), who found an average $17 \%$ decline in the isometric torque measured during an MVC of the human plantarflexor muscle following 90-180 days in microgravity. Individual variability was also noted: 12 of the 14 cosmonauts showed decreases in torque ranging from 2 to $37 \%$, while two subjects showed slightly increased MVCs. In our study, we observed a $21 \%$ decline in the average peak absolute force of the slow type I fiber following a 17-day space flight, while in individual astronauts the change ranged from 12 to $40 \%$. Currently, it is not known whether the observed variability among individuals is caused by a true difference in susceptibility to microgravity or results from variable amounts of in-flight countermeasure exercise. The average peak force for the post-flight soleus type IIa fibers was $25 \%$ lower than the pre-flight value - a decline somewhat greater than that observed for the type I fibers. 
NOT THE PUBLISHED VERSION; this is the author's final, peer-reviewed manuscript. The published version may be accessed by following the link in the citation at the bottom of the page.

From a quantitative perspective, the most important cause of the decline in peak force is cell atrophy. When our data were corrected for the reduced mass by expressing fiber force in $\mathrm{kNm}^{-2}$, the 17-day space flight resulted in an average $4 \%$ decline in peak force (Widrick et al., 1999). Fig. 2 shows the relationship between peak force $(\mathrm{mN})$ and fiber diameter pre- and post-flight for the type I soleus fibers of subject $B$ (the subject with the greatest microgravity-induced decline in fiber size and peak force). Pre-flight, the majority of fibers had diameters greater than $100 \mu \mathrm{m}$ and peak forces greater than $1 \mathrm{mN}$, while the post-flight fiber diameters were mostly less than $100 \mu \mathrm{m}$ with forces less than $1 \mathrm{mN}$. Fig. 2 also demonstrates the post-flight increase in the expression of type IIa myosin, as reflected by the increased number of type IIa fibers and the appearance of hybrid (type I/IIa) fibers in this subject.

[Journal of Experimental Biology, Vol. 204, No. 18 (September 2001): pg. 3201-3208. Publisher Link. This article is (c) Company of Biologists and permission has been granted for this version to appear in e-Publications@Marquette. Company of Biologists does not grant permission for this article to be further copied/distributed or hosted elsewhere without the express permission from Company of Biologists. 


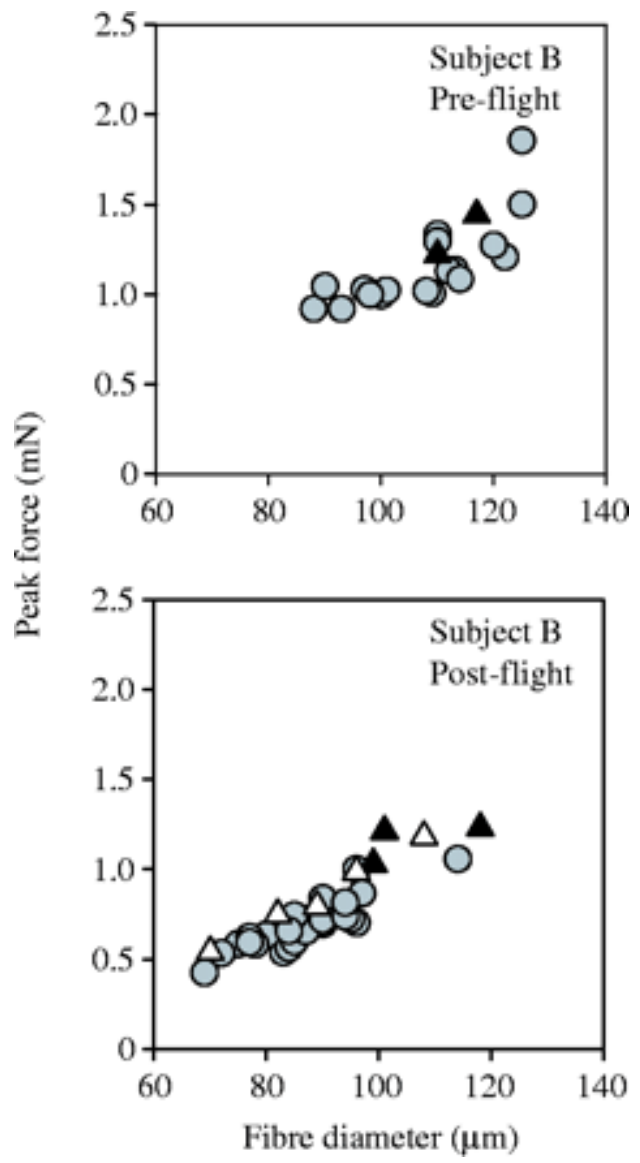

Fig. 2.

Relationship between fiber diameter and peak $\mathrm{Ca}^{2+}$-activated isometric force $\left(P_{0}\right)$ for subject B of the 17-day STS-78 shuttle flight. Each symbol represents the results from a single soleus fiber. Type I fibers, shaded circles; type IIa fibers, filled triangles; type I/IIa fibers, open triangles (redrawn from) (Widrick et al., 1999).

The 17-day space flight affected the fibers of the gastrocnemius less than the soleus fibers. In fact, space flight had no effect on the mean diameter or mass-specific force of fast or slow fibers in the gastrocnemius (Widrick et al., 2001). A small reduction was observed in the average absolute peak force $(\mathrm{mN})$ for the gastrocnemius type I fiber. It is not clear why space flight induced greater atrophy and force decline in soleus than in gastrocnemius fibers. One possibility is that space flight causes a shift in neuronal recruitment favoring flexors over extensors and, within the calf, the gastrocnemius over the soleus. The data of Recktenwald et al. (Recktenwald et al., 1999) support this

[Journal of Experimental Biology, Vol. 204, No. 18 (September 2001): pg. 3201-3208. Publisher Link. This article is (c) Company of Biologists and permission has been granted for this version to appear in e-Publications@Marquette. Company of Biologists does not grant permission for this article to be further copied/distributed or hosted elsewhere without the express permission from Company of Biologists. 
hypothesis because they observed a shift towards a higher activation of the gastrocnemius relative to the soleus post-flight compared with pre-flight during treadmill walking in the rhesus monkey. However, mean integrated electromyographic activity per day recorded from the same STS-78 astronauts that we studied showed that soleus activity was greater in-flight than pre- or post-flight, while gastrocnemius activity was unaltered by flight (Fig.6) (Edgerton et al., 2001). These data indicate that the selective atrophy of the soleus compared with the gastrocnemius fibers in the STS-78 flight was not explained by a greater relative decline in the in-flight soleus EMG activity. A second possibility is that the atrophy relates to the initial fiber size. Both Edgerton et al. (Edgerton et al., 1995) and Widrick et al. (Widrick et al., 1999) observed that muscles with large-diameter fibers pre-flight showed greater atrophy than muscles with smaller average pre-flight diameters. Since the soleus type I fibers are significantly larger in diameter than the gastrocnemius type I fibers, this may in part explain their greater atrophy following microgravity (Fitts et al., 2000).

\section{Maximal shortening velocity and peak power}

Experiments studying rats and humans have consistently demonstrated that the maximal shortening velocity $\left(V_{0}\right)$ of the calf muscles increases as a result of space flight (Caiozzo et al., 1994; Caiozzo et al., 1996; Goubel, 1997; Lambertz et al., 2000; Widrick et al., 1999). Caiozzo and colleagues used the force-velocity relationship to calculate the maximal shortening velocity $\left(V_{\max }\right)$ of the rat soleus and found a $14 \%$ and $20 \%$ increase following 6 days (Caiozzo et al., 1994) and 14 (Caiozzo et al., 1996) days of space flight, respectively. In both flights, the increased muscle velocity was associated with an increased expression of the fast type IIx myosin and a decline in expression of the slow type I myosin. Similar results were obtained when the velocity of human plantar flexors was evaluated following 36 month Mir flights. Goubel (Goubel, 1997) found a significant spaceflight-induced increase in plantar flexor velocity in six out of seven subjects when velocity was measured during a contraction at $15 \%$ of peak power. Consistent with this result, Lambertz et al. (Lambertz et al., 2000) recently reported an average $31 \%$ increase in the shortening velocity during a $10 \%$ MVC for 14 cosmonauts following

[Journal of Experimental Biology, Vol. 204, No. 18 (September 2001): pg. 3201-3208. Publisher Link. This article is (C) Company of Biologists and permission has been granted for this version to appear in e-Publications@Marquette. Company of Biologists does not grant permission for this article to be further copied/distributed or hosted elsewhere without the express permission from Company of Biologists. 
90-180 days in space. As with muscle atrophy, considerable variability was observed: the velocity increases ranged from 4 to $75 \%$.

Widrick et al. (Widrick et al., 1999) studied the effects of a 17day space flight on the single-fiber contractile properties of fibers isolated from the soleus and gastrocnemius muscles of four crew members. Maximal fiber shortening velocity was determined using the unloaded slack test technique (fiber $V_{0}$ ) and calculated from the forcevelocity relationship ( $\left.V_{\max }\right)$. Importantly, in the soleus, the type I fiber $V_{0}$ and $V_{\max }$ increased by 30 and $44 \%$, respectively. Similar increases were observed in the soleus type IIa fiber, in which $V_{0}$ increased by $55 \%$ post-flight. The gastrocnemius fibers were less affected by space flight: the slow type I fibers from this muscle showed a $22 \%$ increase in $V_{0}$, while this variable was unaltered in the fast type IIa fibers.

The data of Widrick et al. (Widrick et al., 1999) indicate that the space-flight-induced increase in the shortening velocity of the plantar flexor muscles is in part due to an increased velocity of the individual fiber types and not simply the result of an increased expression of fast-type myosin. Although we did observe an increase in the number of fibers expressing fast-type myosin post-flight, the significant increase in the velocity of the slow type I and fast type IIa fibers could not be explained by an altered myosin heavy chain isozyme content. The cause of the microgravity-induced increase in fiber $V_{0}$ and $V_{\max }$ is unknown. We did observe an increase in the content of the myosin light chain 3 in the slow soleus fibers post-flight; however, the increase did not show a significant correlation with $V_{0}$. Widrick et al. (Widrick et al., 1999) proposed that the increased fiber $V_{0}$ might be caused by a selective loss of the thin filament actin. Riley et al. (Riley et al., 2000) demonstrated that microgravity did indeed cause a selective loss of actin relative to myosin, and proposed that this change should increase the spacing between the thick and thin filaments. As a result, the cycling cross-bridges would be expected to detach sooner which, in turn, would reduce the internal drag that develops during the final portion of the cross-bridge stroke. The reduced drag would allow for an increased fiber $V_{0}$. The thin filament concentration in the A-band was reduced by $26 \%$ post-flight, which resulted from a $17 \%$ reduction in the number of thin filaments and a $9 \%$ increase in the number of filaments too short to penetrate into the overlap A-band region. Fig. 3 presents a schematic representation of

[Journal of Experimental Biology, Vol. 204, No. 18 (September 2001): pg. 3201-3208. Publisher Link. This article is (C) Company of Biologists and permission has been granted for this version to appear in e-Publications@Marquette. Company of Biologists does not grant permission for this article to be further copied/distributed or hosted elsewhere without the express permission from Company of Biologists. 
the thin and thick filament layout in a normal and an atrophic sarcomere.
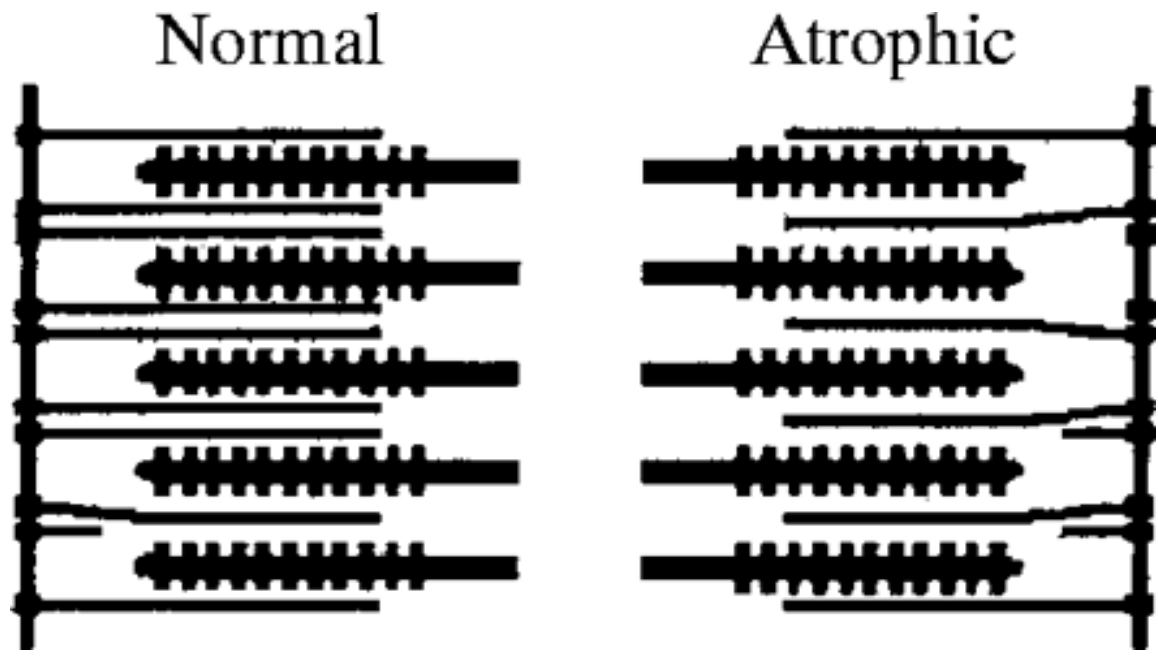

Fig. 3.

Schematic representation of the in vivo status of thin-filament packing density and spacing in half a sarcomere from a normal pre-flight muscle and in half a sarcomere from an atrophic muscle after a 17-day space flight in humans. Subsequent to atrophy after space flight, short thin filaments increased in number by $9 \%$, and $17 \%$ of the thin filaments were lost. These changes summed to produce a $26 \%$ decrease in thin filament density in the overlap A-band region (redrawn) (from Riley et al., 2000).

In rats, 6-14 days of space flight caused a $16-20 \%$ decline in the peak power of the soleus (Caiozzo et al., 1994; Caiozzo et al., 1996). This decline occurred despite a significant increase in $V_{\max }$ and was a direct result of muscle atrophy and the reduced force-generating capacity of the muscle. In the single-fiber study of Widrick et al. (Widrick et al., 1999), the peak power of the soleus type I fiber declined by approximately $20 \%$ in two of the four crew members. In the other two crew members, the increase in fiber velocity was enough to compensate for the reduction in force such that no significant change was observed in peak power. In all four astronauts, the force and velocity utilized to generate peak power were lower and higher, respectively, compared with the pre-flight fibers. Fig.4 shows composite force-velocity and force-power relationships for the preand post-flight slow type I fibers from astronaut $\mathrm{B}$. The plots clearly demonstrate the reduced peak force $(\mathrm{mN})$ and power and the increased $V_{\max }$ in the post-flight fibers.

[Journal of Experimental Biology, Vol. 204, No. 18 (September 2001): pg. 3201-3208. Publisher Link. This article is (C) Company of Biologists and permission has been granted for this version to appear in e-Publications@Marquette. Company of Biologists does not grant permission for this article to be further copied/distributed or hosted elsewhere without the express permission from Company of Biologists. 


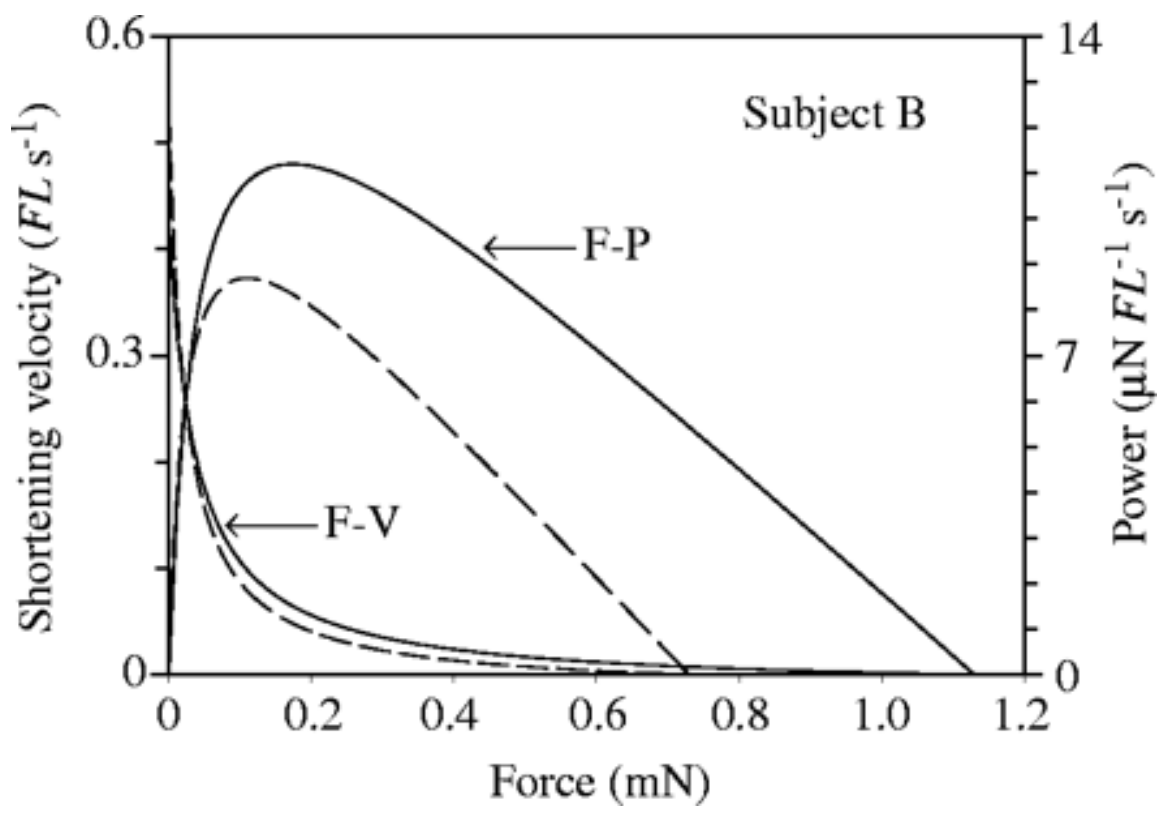

Fig. 4.

Force-velocity (F-V) and force-power (F-P) relationships of pre- and post-flight soleus fibers from subject $B$ of the 17-day STS-78 shuttle flight. Continuous lines represent composite pre-flight force-velocity and force-power relationships. Broken lines represent post-flight force-velocity and force-power relationships (redrawn from)(Widrick et al., 1999). $F L$, fiber length.

Antonutto et al. (Antonutto et al., 1998; Antonutto et al., 1999) examined the maximal leg power of astronauts following space flights lasting 21-180 days. In one astronaut, leg power was reduced by 54\% after only 21 days of weightlessness. This change was considerable greater than the decline in single-fiber peak power following a 17-day flight (Widrick et al., 1999) and suggests that factors other than fiber atrophy contributed to the decline. One possibility is that space flight altered the motor recruitment pattern, resulting in a greater activation of flexors than extensors, and that this contributed to the reduce power measured during a maximal leg extension test (Fitts et al., 2000). The time course of the decline in peak power to a new microgravity steady state was approximately 6 months, a value similar to that observed for muscle mass and force (Greenleaf et al., 1989). 


\section{Substrate and metabolic changes with microgravity and their impact on fatigue}

Observations from both space flight and models of weightlessness suggest that microgravity reduces the ability of limb skeletal muscle to oxidize free fatty acids and increases the utilization of carbohydrates during exercise. Baldwin et al. (Baldwin et al., 1993) showed that muscle homogenates prepared from space-flown rats had a reduced ability to oxidize free fatty acids. Consistent with this observation, we observed that 2 weeks of hindlimb unloading increased the utilization of glycogen and the production of lactate during electrical stimulation of the rat soleus muscle (Grichko et al., 2000). The latter observation was not simply the result of an increased number of fast-twitch glycolytic fibers because increased glycogen depletion and lactate production were observed in the slow type I fibers. These substrate changes have functional consequences because both weightlessness and hindlimb unweighting have been shown to increase the fatigability of the soleus muscle (McDonald et al., 1992). These metabolic adaptations do not appear to be caused by a reduced aerobic enzyme capacity because the activity of marker enzymes of the $\beta$-oxidative pathway and the Krebs cycle were not altered by either space flight or models of weightlessness in either rats or humans (Fitts et al., 2000).

We have observed that both hindlimb unloading in rats and bed rest in humans increased the resting muscle glycogen content of the soleus (Grichko et al., 2000). However, 17 days of space flight had no effect on soleus glycogen content in humans (R. H. Fitts, V. P. Grichko and M. L. De La Cruz, unpublished observations). This result can be observed in Fig.1. The small particles surrounding the myofilaments are glycogen particles, and equal numbers are observed in the preflight (Fig.1A) and post-flight (Fig.1B) micrographs. The lack of a significant increase in muscle glycogen content in this study may have resulted from an inadequate caloric intake. Stein et al. (Stein et al., 1999) reported that the crew from this flight were in negative caloric balance. Thus, with an adequate caloric intake, space flight may induce an increase in resting muscle glycogen content similar to that observed following bed rest.

[Journal of Experimental Biology, Vol. 204, No. 18 (September 2001): pg. 3201-3208. Publisher Link. This article is (C) Company of Biologists and permission has been granted for this version to appear in e-Publications@Marquette. Company of Biologists does not grant permission for this article to be further copied/distributed or hosted elsewhere without the express permission from Company of Biologists. 
The cause of the increased reliance on carbohydrates following space flight and models of weightlessness is unknown (Baldwin et al., 1993; Grichko et al., 2000). As stated above, the increase does not seem to be caused by an altered aerobic enzyme capacity. Our working hypothesis is that it results from a combination of a change in substrate regulation at the onset of exercise and an inhibition of carnitine palmitoyltransferase (CPTI), the rate-limiting enzyme for the oxidation of long-chain fatty acids. We have previously shown that steady-state skeletal muscle blood flow is not altered by hindlimb unloading (McDonald et al., 1992). However, recent evidence suggests that the rate of increase in blood flow with the onset of exercise may be depressed. Hindlimb unloading has been shown to reduce endothelium-dependent dilation in soleus feed arteries, and soleus blood flow measured using the microsphere technique was depressed in the first minute of exercise following 28 days of hindlimb unloading (Jasperse et al., 1999)(M. D. Delp, personal communication). Thus, the possibility exists that models of weightlessness and space flight may reduce the rate at which muscle blood flow increases with the onset of exercise. This, in turn, would increase the rate of creatine phosphate and ATP hydrolysis, increase ADP, AMP and inorganic phosphate production and stimulate glycolysis. The elevated glycolytic rate would increase the production of acetyl-CoA and malonyl-CoA. The latter is a known inhibitor of CPTI and, thus, fatty acid oxidation would be reduced. In addition, space flight and models of weightlessness may reduce the activity of adenosine-5'monophosphate-activated protein kinase (AMPK). This enzyme appears to be a metabolic master switch controlling the activity of various metabolic pathways (Winder and Hardie, 1999). Of importance here, a reduced AMPK activity would reduce the inactivation of the target protein acetyl-CoA carboxylase (ACC), which would allow levels of the product of ACC (malonyl-CoA) to remain high. It is also possible that the exercise-induced mobilization of fatty acids from the adipose sites may be depressed by space flight or models of weightlessness. This would reduce fatty acid oxidation by limiting their delivery to and uptake by the skeletal muscle.

[Journal of Experimental Biology, Vol. 204, No. 18 (September 2001): pg. 3201-3208. Publisher Link. This article is (C) Company of Biologists and permission has been granted for this version to appear in e-Publications@Marquette. Company of Biologists does not grant permission for this article to be further copied/distributed or hosted elsewhere without the express permission from Company of Biologists. 


\section{Muscle fiber damage following space flight}

Muscle fiber damage following space flight is a major problem. Currently, there are no data on astronauts that address this issue, but rat studies have shown the problem to be caused by re-loading postflight (Riley et al., 1996). These studies were recently reviewed in detail (Fitts et al., 2000), so only a few of the key data will be described here. The initial evidence of fiber damage post-flight came from the Russian Cosmos flights (Riley et al., 1990; Riley et al., 1992). The 14-day Cosmos 2044 flight showed that rats killed 8-11h after landing exhibited extensive sarcomere disruption and edema but minimal tissue necrosis and macrophage and satellite cell activation (Riley et al., 1992). Fig.5 shows a longitudinal section of adductor longus muscle fibers from a rat flown on the Cosmos 2044 mission. The central muscle fiber exhibits foci of sarcomere eccentric-like contraction damage, representing myofilament disruption. On average, $15 \%$ of the soleus fibers and $44 \%$ of the adductor longus fibers showed damage in the post-flight sections.

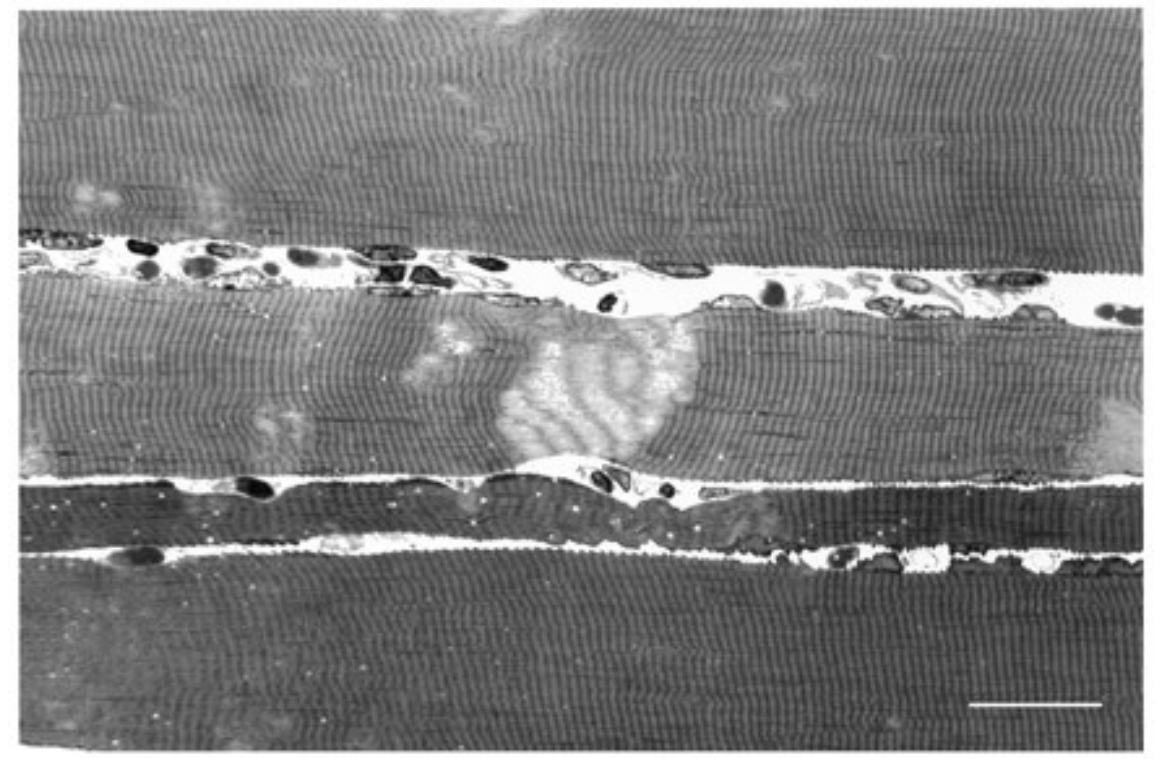

Fig. 5.

Toluidine-Blue-stained, longitudinal semithin section of adductor longus muscle fibers from a rat orbited in microgravity for 2 weeks in Cosmos biosatellite mission 2044 and returned to terrestrial gravity loading for approximately $10 \mathrm{~h}$ before tissue fixation. The central muscle fiber exhibits large and small lighter-stained foci of sarcomere

[Journal of Experimental Biology, Vol. 204, No. 18 (September 2001): pg. 3201-3208. Publisher Link. This article is (C) Company of Biologists and permission has been granted for this version to appear in e-Publications@Marquette. Company of Biologists does not grant permission for this article to be further copied/distributed or hosted elsewhere without the express permission from Company of Biologists. 
NOT THE PUBLISHED VERSION; this is the author's final, peer-reviewed manuscript. The published version may be accessed by following the link in the citation at the bottom of the page.

eccentric-like contraction damage, representing myofilament disruption. Sarcomere lesions were detected in $44 \%$ of the fibers examined. Scale bar, $42 \mu \mathrm{m}$.

It was not until the 1993 SLS-2 mission, during which rat muscles were examined in space, that it was possible to separate inflight from post-flight changes in cell structure (Riley et al., 1996). The soleus and adductor longus samples collected in-flight showed no evidence of fiber damage. This documented what had previously been suspected, that muscle fiber damage was primarily a post-flight condition resulting from eccentric contractions during re-loading in a normal-gravity environment.

Although the problem of fiber damage post-flight has not been studied in man, it probably occurs because astronauts complain of persistent muscle soreness for up to months post-flight. The microgravity environment has apparently altered the muscle so that it is more susceptible to eccentric-induced contractile damage postflight. Following weightlessness and hindlimb unloading in rats, the slow type I fibers showed preferential damage, which was attributed to the selective recruitment of this fiber type (Riley et al., 1996). The causative factors of fiber damage are not known, but damage might in part relate to cell atrophy and the selective loss of the contractile protein actin (Fitts et al., 2000). Post-flight, any load and strain on the atrophied fiber would be relatively greater and thus more likely to cause damage. At the fibril level, the load would be distributed to fewer actin filaments, which might increase their susceptibility to damage. Other possibilities include changes in the protein titin, the cytoskeletal protein desmin and/or alterations in the dystrophinglycoprotein complex. Titin is a protein known to extend from the Zline to the $\mathrm{M}$-line of the A-band. It is thought to play a role in establishing resting tension and in the orientation of the thick filament myosin (Labeit et al., 1997). Thus, alterations in this protein could cause the thick filament to move from the center of the sarcomere towards the Z-line. A breakdown in desmin and/or reduction or absence of a single component of the dystrophin-glycoprotein complex could result in greater susceptibility of the sarcolemma to contractioninduced damage (Chopard et al., 2001; Lieber et al., 1996).

[Journal of Experimental Biology, Vol. 204, No. 18 (September 2001): pg. 3201-3208. Publisher Link. This article is (C) Company of Biologists and permission has been granted for this version to appear in e-Publications@Marquette. Company of Biologists does not grant permission for this article to be further copied/distributed or hosted elsewhere without the express permission from Company of Biologists. 
NOT THE PUBLISHED VERSION; this is the author's final, peer-reviewed manuscript. The published version may be accessed by following the link in the citation at the bottom of the page.

\section{Concluding remarks}

One of the primary problems associated with weightlessness and models of weightlessness, such as bed rest, is muscle cell atrophy. Extensors atrophy at a faster rate than flexors and, within the plantar flexor group, the antigravity soleus muscle atrophies more than the gastrocnemius. In rats, the slow type I fiber shows selective atrophy, while in humans the fast type II fibers atrophy as much as, if not more than, the slow fibers. This cell wasting leads to a reduced peak force and power. In addition to atrophy, weightlessness causes a selective loss of contractile proteins, with the decline in actin content being greater than that for myosin. The latter may contribute to the spaceflight-induced increase in fiber shortening velocity.

In rats (and perhaps humans), space flight and models of weightlessness increase resting muscle glycogen content, and glycogen depletion and lactate production are accelerated during activity. The increased dependence on glycogen is associated with a reduced ability to oxidize free fatty acids. The reduced ability to oxidize fats may be caused by substrate inhibition of CPTI, the ratelimiting enzyme in fatty acid oxidation.

Finally, muscle fiber damage following space flight has been observed in rats. Although some damage may occur in space, the majority occurs following re-loading upon return to earth. The lesions are similar to those observed following eccentric contractions. The etiology of the increased sensitivity to cell damage following microgravity is unknown, but may be caused by the cell atrophy and reduced actin content and/or to the selective loss of other proteins such as titin, desmin and dystrophin. 
NOT THE PUBLISHED VERSION; this is the author's final, peer-reviewed manuscript. The published version may be accessed by following the link in the citation at the bottom of the page.

\section{Acknowledgements}

This work was supported in part by NASA Grants NAS 9-18768 and NAG 9-1156 to R.H.F. The authors thank the Shuttle Transport System (STS-78) crew and the scientists of the National Aeronautics and Space Administration (NASA) Johnson Space Center. (C) The Company of Biologists Limited 2001

\section{References}

Antonutto, G., Bodem, F., Zamparo, P. and di Prampero, P. E. (1998). Maximal power and EMG of lower limbs after 21 days spaceflight in one astronaut. J. Gravitat. Physiol. 5, 63-66.

Antonutto, G., Capelli, C., Girardis, M., Zamparo, P. and di Prampero, P. E. (1999). Effects of microgravity on maximal power of lower limbs during very short efforts in humans. J. Appl. Physiol. 86, 85-92.

Baldwin, K., Herrick, R., Ilyina-Kakueva, E. and Oganov, V. (1990). Effect of zero gravity on myofibril content and isomyosin distribution in rodent skeletal muscle. FASEB J. 4, 79-83.

Baldwin, K. M., Herrick, R. E. and McCue, S. A. (1993). Substrate oxidation capacity in rodent skeletal muscle: effects of exposure to zero gravity. J. Appl. Physiol. 75, 2466-2470.

Caiozzo, V. J., Baker, M. J., Herrick, R. E., Tao, M. and Baldwin, K. M. (1994). Effect of a spaceflight on skeletal muscle: mechanical properties and myosin isoform content of a sow muscle. J. Appl. Physiol. 76, 1764-1773.

Caiozzo, V. J., Haddad, F., Baker, M. J., Herrick, R. E., Prietto, N. and Baldwin, K. M. (1996). Microgravity-induced transformations of myosin isoforms and contractile properties of skeletal muscle. J. Appl. Physiol. 81, 123-132.

Chopard, A., Pons, F. and Marini, J. F. (2001). Cytoskeletal protein contents before and after hindlimb suspension in a fast and slow skeletal muscle. Am. J. Physiol. 280, R323-R330.

Edgerton, V. R., McCall, G. E., Hodgson, J. A., Gotto, J., Goulet, C., Fleischmann, K. and Roy, R. R. (2001). Sensorimotor adaptations to microgravity in humans. J. Exp. Biol. 204, 3216-3223.

[Journal of Experimental Biology, Vol. 204, No. 18 (September 2001): pg. 3201-3208. Publisher Link. This article is (C) Company of Biologists and permission has been granted for this version to appear in e-Publications@Marquette. Company of Biologists does not grant permission for this article to be further copied/distributed or hosted elsewhere without the express permission from Company of Biologists. 
NOT THE PUBLISHED VERSION; this is the author's final, peer-reviewed manuscript. The published version may be accessed by following the link in the citation at the bottom of the page.

Edgerton, V. R., Zhou, M.-Y., Ohira, Y., Klitgaard, H., Jiang, B., Bell, G., Harris, B., Saltin, B., Gollnick, P. D., Roy, R. R., Day, M. K. and Greenisen, M. (1995). Human fiber size and enzymatic properties after 5 and 11 days of spaceflight. J. Appl. Physiol. 78, 1733-1739.

Fitts, R. H., Riley, D. R. and Widrick, J. J. (2000). Microgravity and skeletal muscle. J. Appl. Physiol. 89, 823-839.

Goubel, F. (1997). Changes in mechanical properties of human muscle as a result of spaceflight. Int. J. Sports Med. 18, S285-S287.

Greenleaf, J. E., Bulbulian, R., Bernauer, E. M., Haskell, W. L. and Moore, T. (1989). Exercise-training protocols for astronauts in microgravity. J. Appl. Physiol. 67, 2191-2204.

Grichko, V. P., Heywood-Cooksey, A., Kidd, K. R. and Fitts, R. H. (2000). Substrate profile in rat soleus muscle fibers after hindlimb unloading and fatigue. J. Appl. Physiol. 88, 473-478.

Jasperse, J. L., Woodman, C., Price, E., Hasser, E. and Laughlin, M. (1999). Hindlimb unweightening decreases cNOS gene expression and endothelium-dependent dilation in rat soleus feed arteries. J. Appl. Physiol. 87, 1476-1482.

Jiang, B., Ohira, Y., Roy, R., Nguyen, Q., Ei, I.-K., Oganov, V. and Edgerton, $\boldsymbol{V}$. (1992). Adaptation of fibers in fast-twitch muscle of rats to spaceflight and hindlimb suspension. J. Appl. Physiol. 73, 58S-65S.

Labeit, S., Kolmerer, B. and Linke, W. A. (1997). The giant protein titin. Circulation Res. 80, 290-294.

Lambertz, D., Perot, C., Kaspranski, R. and Goubel, F. (2000). Effects of long-term spaceflight on mechanical properties of muscles in humans. J. Appl. Physiol. 90, 179-188.

Lieber, R. L., Thornell, L. E. and Fridén, J. (1996). Muscle cytoskeletal disruption occurs within the first $15 \mathrm{~min}$ of cyclic eccentric contraction. J. Appl. Physiol. 80, 278-284.

McDonald, K. S., Delp, M. D. and Fitts, R. H. (1992). Fatigability and blood flow in the rat gastrocnemius-plantaris-soleus after hindlimb suspension. J. Appl. Physiol. 73, 1135-1140.

[Journal of Experimental Biology, Vol. 204, No. 18 (September 2001): pg. 3201-3208. Publisher Link. This article is (C) Company of Biologists and permission has been granted for this version to appear in e-Publications@Marquette. Company of Biologists does not grant permission for this article to be further copied/distributed or hosted elsewhere without the express permission from Company of Biologists. 
NOT THE PUBLISHED VERSION; this is the author's final, peer-reviewed manuscript. The published version may be accessed by following the link in the citation at the bottom of the page.

Nicogossian, A. E., Pool, S. L. and Uri, J. J. (1994). Historical perspectives. In Space Physiology and Medicine, chapter 1 (ed. A. E. Nicogossian, C. L. Huntoon and S. L. Pool), pp. 3-49. Malvern, PA: Lea \& Febiger.

Ohira, Y., Jiang, B., Roy, R., Oganov, V., Ilyina-Kakueva, E., Marini, J. F. and Edgerton, V. R. (1992). Rat soleus muscle fiber responses to 14 days of spaceflight and hindlimb suspension. J. Appl. Physiol. 73, 51S-57S.

Recktenwald, M. R., Hodgson, J. A., Roy, R. R., Riazanski, S., McCall, G. E., Kozlovskaya, I., Washburn, D. A., Fanton, J. W. and Edgerton, V. R. (1999). Effects of spaceflight on rhesus quadrupedal locomotion after return to $1 G$. J. Neurophysiol. 81, 2451-2463.

Riley, D. A., Bain, J. L. W., Thompson, J. L., Fitts, R. H., Widrick, J. J., Trappe, S. W., Trappe, T. A. and Costill, D. L. (2000). Decreased thin filament density and length in human atrophic soleus muscle after spaceflight. J. Appl. Physiol. 88, 567-572.

Riley, D. A., Ellis, S., Giometti, J. F., Hoh, Y., Ilyina-Kakueva, E., Oganov, V. S., Slocum, G. R., Bain, J. W. L. and Sedlak, F. R. (1992). Muscle sarcomere lesions and thrombosis after spaceflight and suspension unloading. J. Appl. Physiol. 73, 33s-43s.

Riley, D. A., Ellis, S., Slocum, G. R., Sedlak, F. R., Bain, J. L. W., Krippendorf, B. B., Lehman, C. T., Macias, M. Y., Thompson, J. L., Mijayan, K. and De Bruin, J. A. (1996). In-flight and postflight changes in sketetal muscles of SLS-1 and SLS-2 spaceflown rats. J. Appl. Physiol. 81, 133-144.

Riley, D. A., Ilyina-Kakueva, E. I., Ellis, S., Bain, J. L. W., Slocum, G. R. and Sedlak, F. R. (1990). Skeletal muscle fiber, nerve and blood vessel breakdown in space-flown rats. FASEB J. 4, 84-91.

Stein, T. P., Leskiw, M. J., Schluter, M. D., Hoyt, R. W., Lane, H. W., Gretebeck, R. E. and LeBlanc, A. D. (1999). Energy expenditure and balance during spaceflight on the space shuttle. Am. J. Physiol. 276, R1739-R1748.

Tischler, M. E., Henriksen, E. J., Munoz, K. A., Stump, C. S., Woodman, C. R. and Kirby, C. R. (1993). Spaceflight on STS-48 and earth-based

[Journal of Experimental Biology, Vol. 204, No. 18 (September 2001): pg. 3201-3208. Publisher Link. This article is (C) Company of Biologists and permission has been granted for this version to appear in e-Publications@Marquette. Company of Biologists does not grant permission for this article to be further copied/distributed or hosted elsewhere without the express permission from Company of Biologists. 
NOT THE PUBLISHED VERSION; this is the author's final, peer-reviewed manuscript. The published version may be accessed by following the link in the citation at the bottom of the page.

unweighting produce similar effects on skeletal muscle of young rats. J. Appl. Physiol. 74, 2161-2165.

Widrick, J. J., Knuth, S. K., Norenberg, K. M., Romatowski, J. G., Bain, J. L. W., Riley, D. A., Karhanek, M., Trappe, S. W., Trappe, T. A., Costill, D. L. and Fitts, R. H. (1999). Effect of a 17 day spaceflight on contractile properties of human soleus fibers. J. Physiol., Lond. 516, 915-930.

Widrick, J. J., Romatowski, J. G., Norenberg, K. M., Knuth, S. T., Bain, J. L. W., Riley, D. A., Karhanek, M., Gettleman, G., Trappe, S. W., Trappe, T. A., Costill, D. L. and Fitts, R. H. (2001). Functional responses of slow and fast human gastrocnemius muscle fibers to a 17 day spaceflight. J. Appl. Physiol. 90, 2203-2211.

Winder, W. W. and Hardie, D. G. (1999). AMP-activated protein kinase, a metabolic master switch: possible roles in Type 2 diabetes. Am. J. Physiol. 277, E1-E10.

Zange, J., Muller, K., Schuber, M., Wackerhage, H., Hoffmann, U., Gunther, R. W., Adam, G., Neuerburg, J. M., Sinitsyn, V. E., Bacharev, A. O. and Belichenko, O. I. (1997). Changes in calf muscle performance, energy metabolism and muscle volume caused by long term stay on space station MIR. Int. J. Sports Med. 18, S308S309.

\section{Author Affiliations}

${ }^{1}$ Department of Biology, Marquette University, Milwaukee, WI 53201, USA,

${ }^{2}$ Department of Cellular Biology and Anatomy, Medical College of Wisconsin, Milwaukee, WI 53226, USA and

${ }^{3}$ Department of Exercise and Sport Sciences, Oregon State University, Corvallis, OR 97331, USA

*e-mail: Robert.fitts@mu.edu

[Journal of Experimental Biology, Vol. 204, No. 18 (September 2001): pg. 3201-3208. Publisher Link. This article is (C) Company of Biologists and permission has been granted for this version to appear in e-Publications@Marquette. Company of Biologists does not grant permission for this article to be further copied/distributed or hosted elsewhere without the express permission from Company of Biologists. 